\title{
Socio -Psychological Alienation and Power Relation-A post structuralist reading of the Blacks, Browns and Whites in the Novels of Toni Morrison's The Bluest eye, Caryl Phillips's The Final Passage, Mulk Raj Anand's Untouchable
}

\author{
Dr. Beula Esther \\ Asst. Prof. In English Kalai Kaviri College of Fine Arts Tiruchirappalli-01
}

\section{Introduction}

Pre-historically, mankind emerging responsible to and for it, man has been divided into pseudo-species (tribes and nation, caste and classes) each with its own identity. When these roles of identity are questioned or assimilated or imbibed, results, in alienation of man from man. The impact of social power relations on individuals who do not know the identity of their own existence end up in existential impasse. For interaction of man with society needs courage and faith, and when one has no roots in society floats and their by resulting in the isolation of insanity

In the concept of power as war or politics as war as according to Claus Waltz (Foucault, 90) the individual gets repressed and he is subjected to conflict in between struggle and submission. Social institution become power bodies, which is called as "microphysics" of power by Michel Foucault and become apparatus of power, "[...] which are the multiple forms of subjugation that have a place and function within the social organism"(Foucault,35).The paradigmatic study of power relations on different races of White, Brown and Black with reference to the text chosen for the study of both as schizophrenic and alienation beings on account of the effect of the individuals socio- psychological estrangement is the objective of this research paper.

\section{Socio-Psychological Alienaton}

The social ideology of bourgeois community then men as bread winners and women as bread bakers typify their sphere and establish the power of authority not as contending forces of egoism and collectivism but as neutral forces of competition and combination thereby giving no room for subversion of revolt but develops a domestic apparatus in which the man as a husband and woman as a wife has to act as arbitrators not between the warring ideas of other family members but between the resolution of their contradictions in their exercise of power among themselves

In this sense Leila's relationship with Michael in Caryl Phillips The Final Passage is at vortex of combination and no element of subversion of revolt knowing well the intelligence of Leila. Therefore he seizes the power of Leila's intelligence within the context of social and domestic order of the society. In the Sandy Bay men and women had to work in the sugarcane fields of the white for hours getting only meagre income realizing fully well their inability to fly high in the socio-economic firmament. Many black men took to drinking and spending their time as lotus-eaters without caring for the present and future, as even Bjork has pointed out,

"Black males, unable to assert themselves as productive members of

Society, felt their masculinity debased not only by white males but also ironically by black females who were often the sole bread winners in the white man's kitchen"'[Bjork,17].

In The Bluest eye of Toni Morrison, Pauline Breedlove's family's transplantation to the north created in Pauline, Pecola's mother, a certain nervous pretentiousness got her leaving in the seemingly fragmented and hostile community, people and the movies. Her job in the house of Fisher's has given her scope to exercise her original artistic sensibility that otherwise cannot find expression. But it is not until her job at Fisher's that she can again;

[...] Arrange things, clean things, line things up in neat rows, here the foot flopped around on deep pile carpets, and there was no uneven sound. Here she found beauty, order, cleanliness,[..] power praise, and luxury were her's in this household. They even gave her what she had never had-a nick name-Polly. It was her pleasure to stand in her kitchen 
at the end of a day and survey her handiwork (TBE,101]

Moreover her job with Fisher's provides her with semblance of acceptance and community she cannot create in her home and neighbourhood. At home Pauline's loneliness is further increased because of her husband Cholly's futile struggle to support them decently and in their attempt to irk out their existence they never build them on the bed rock of lock but destroy every possibility of love and use their children only as weapons against each other, herby the harmony of the family and the peace of the children are shattered to pieces.

In the Untouchable what is found missing as a socio-psychological factor in mutual respect and honour for the high castes expect the low castes to obey them implicitly without showing any sign of protest. Bakha, born as a sweeper, he had to clean the town called Buland Shas and he does this job honestly and sincerely. Respecting duty and performing it to the satisfaction of all is an idea that he has learnt from his mother who died "but so loving ,so good and with all generous, giving always giving, mother giver of life, Mahalakshmi" (UNT,16)

All these mothers who were bread winners of the family, who value marriage as harbinger of domestic bliss and happiness and also their immense faith on the role of the women as wife ever ready to sacrifice everything at the altar of the man or her husband's are apparatus of wish thereby relegating herself to the secondary position ever projecting her husband's image as the ruler and bread winner of the domestic front. In this context Michael in "The Final Passage" with only the authority on the basis of his gender did not know how to establish his name as the best breadwinner for which he had no potentialities of education nor the land he lived provided him with all amenities for material expansion. He was in this sense self alienated ever ready to reap the benefit of his gender superiority, as a being in Sandy Bay but in his being there was a particular historical world of Sandy Bay that of alienated labour.

In The Bluest eye of Toni Morrison portrayal of Cholly Breedlove's freedom as a consequence of the socio psychological affectation by his and the dominant society he is spaced with explains how he is condemned to be free and alienated from himself, his family and the whites:

Dangerously free. Free to feel to whatever he felt - fear, guilt, shame, love, grief, pity. Free to be tender or violent, to whistle or to weep. Free to sleep in doorways or between the white sheets of a singing woman. Free to take a job, free to leave it. He could go to jail and not feel imprisoned, for he had already seen the furtiveness in the eyes of his jailor, free to say," no,suh," and smile, for he had already killed three white men . Free to take women's insults, for his body had already cradled that head in his arms. Free to be gentle when she was sick or mop her flow, for she knew what and where his maleness was. He was free to drink himself into a silly helplessness, for he had already been a dandy dancer, done thirty days on a chain gang, and picked a woman's bullet out of the calf of his leg. He was free to leave his fantasies and free even to die, the how and when or which held no interest for him[..] abandoned in a junk heap by his mother, rejected for a crap game by his father, there was nothing more to lose .He was alone with his own perceptions and appetites, and they alone interested him. (TBE,125-126)

In his life he did not discharge any responsibility either a son or as a grandson, the new role he had to interrupt after getting himself married to Pauline as a husband and show love, affection, care and attention to children was an alien factor for him

But the aspect of married life that dumbfounded him and rendered him totally dysfunctional was the appearance of children. Having no idea of how to raise children, and having never watched any parent raise himself, he could not comprehend what relationship should be. Had he been interested in the accumulation of things , he could have thought of them as his material heirs; had he needed to prove himself to some nameless 'others', he could have wanted them to excel in his own image and for his own sake. Had he not been alone in this world since he was thirteen, knowing only a dying old woman he felt responsible for him, but whose age, sex, interest were so remote from his own, he might have felt a stable connection between himself and the children. As it was he reacted to them, and his reactions were based on what he felt at the moment. [TBE, 126]

Bakha in Untouchable represent the untouchables through serving the members of the high caste slavishly and with timidity, do not receive any welfare from them, they consider them as beings of pollution but 
Socio-Psychological Alienation and Power Relation-A post structuralist reading of the Blacks,

they ironically cleaned the pollution off them. In their absence the society had to sink in stink and dirt but the reward they get for their remarkable services is this "they ought to be wiped of the surface of the earth" (UNT,56).In Untouchable socio-psychology has its roots in the hoary casteism where in sweepers are untouchables because of their work and the high caste Hindus consider them as embodiment of pollution without truly understanding that in the matter of mental conduct and deed of mind man is weighed good by the cosmic force and not the through his physical conduct and deed. Knowing well that the price Bakha would get out of his good conduct to be called by names like 'low caste' vermins','swine', 'cock-eyed son of a bow legged scorpion', 'dog', 'brute', 'dirty dog', 'son of a bitch', 'offspring of a pig etc.'[UNT,52-53] ,he had no scope for confronting the challenge ,all because of his ugly existence.

\section{Conclusion}

Relationships between masters and slaves, high castes and low castes, superior race and inferior, are internal bonds in which the' other 'shapes the consciousness of each. The master and slave, the dominant and the subjected were not social, the one being 'better off' and the 'worse off', the one being independent, authoritative and cozy and the other dependent, submissive and most uncomfortable. The superior and the dominant because of the singularity and the marginalized and inferior is strangled because of his sub human existence. Aspiration for the power, mode,morms, beauty, money, of the hegemonies society by the subjugated individuals causes breaches in his final bondage and drive insane enlightenment with right kind of rationalization can move then towards upward direction and at some point. Both may melt and that will be golden age of man.

\section{Works Cited}

[1]. Anand,Mulk Raj. Untouchable .Bombay:kutub,1935

[2]. Bjork,Patrick Bryce.The Novel of Toni Morrison: The Search For Self And Place Within The Community.New York: Peter long Publishing Inc, 1992.

[3]. Foucault,Michel. Power/Knowledge : Selected Interviews and Other Writings 1971-1972.ed.,Colin Gordon,Leo Marshall, Et all., New York : Pantheon, 1980.

[4]. Morrison,Toni.The Bluest Eye.New York : Holt Rinehart,1970.

[5]. Phillips,Caryl. The Final Passage.London:Faber and Faber,1985. 